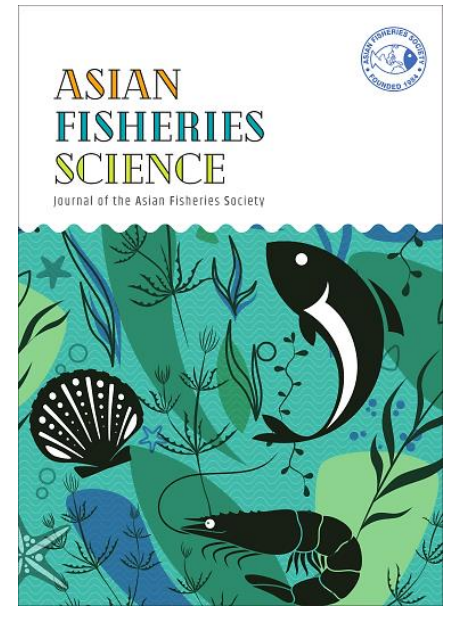

(C)Asian Fisheries Society

ISSN: 0116-6514

E-ISSN: 2073-3720

https://doi.org/10.33997/j.afs.2020.33.3.001

\section{Growth and Carotenoid Production of Dunaliella salina (Dunal) Teodoresco, 1905 Cultured at Different Salinities}

\author{
HELENA KHATOON ${ }^{1, *}$, GREGORY TAN GUAN YUAN² ${ }^{2}$ ANISUL ISLAM MAHMUD ${ }^{3}$, \\ MOHAMMAD REDWANUR RAHMAN ${ }^{1}$ \\ 'Department of Aquaculture, Faculty of Fisheries, Chittagong Veterinary and Animal Sciences University, 4225 Khulshi, \\ Chittagong, Bangladesh \\ ${ }^{2}$ Aquatic Animal Health and Therapeutics Laboratory, Institute of Bioscience, Universiti Putra Malaysia, 43400 Serdang, \\ Selangor, Malaysia \\ ${ }^{3}$ DVI Labo, 2 Rue du Commandant Robert Malrait, 27300 Bernay, France
}

*E-mail: helena@cvasu.ac.bd | Received: 10/03/2020; Accepted: 14/08/2020

\begin{abstract}
Microalgae species have been widely used as an alternative source for pigment extraction. The genus Dunaliella has been commercially cultured for its carotenoid pigments. Carotenoid is one of the commercially important pigments widely used in various industries. In the present study, different salinities such as $0.3,0.5,0.7$ and $0.9 \mathrm{M}$ were used to culture Dunaliella salina (Dunal) Teodoresco, 1905 to determine the ideal salinity for the growth and carotenoid production for 12 days. Growth was monitored daily with respect to cell density. Carotenoids were extracted from samples every alternate day. Results showed that Dunaliella salina had highest $(P<0.05)$ cell density when cultured at $0.7 \mathrm{M}$ salinity compared to other salinities. Similarly, specific growth rate $\left(0.53 \mu\right.$. day $\left.^{-1}\right)$ and carotenoid contents $(5.015$ mg. $\left.L^{-1}\right)$ were found highest $(P<0.05)$ at $0.7 \mathrm{M}$ salinity compared to the other salinities. This study illustrated that Dunaliella salina favoured moderately high salinities (0.7M) for optimum cell growth and the production of carotenoid.
\end{abstract}

Keywords: microalgae, pigment, cell density, salinity, carotenoid

\section{Introduction}

Dunaliella salina is a microalga which is the richest sources of natural carotenoids ( $X u$ et al., 2016). Dunaliella salina, the major accumulated carotenoid is $\beta$-carotene, which is stored in globules of lipid and proline-rich, carotene globule protein in the interthylakoid spaces of the chloroplast ( $\beta C$-plastoglobuli) (Ben-Amotz et al., 1982; Lamers et al., 2012; Davidi et al., 2015).

This natural carotene contains pigments red, yellow to orange used as a colourant in the feed industry (Lamers et al., 2012). Dunaliella salina contains almost 5-10 mg $\beta$-carotene.g-1 dry weight under normal growth which is similar to other green microalgae such as Chlorella, Chlorococcum, Scenedesmus, Coelastrum, Desmodesmus (Del Campo et al., 2007). However, the carotene production is affected by many factors such as salinity, light intensity, nutrient deprivation and temperature. Carotenoid production can increase as much as $10 \%$ of dry weight when this species is cultured in stress conditions such as high salinity, high light intensity, nutrient deprivation and extreme temperatures (Ben-Amotz et al., 1982; Ben-Amotz and Avron, 1983; Borowitzka et al., 1990; Shaish et al., 1993; Ben-Amotz, 1996; Kleinegris et al., 2009).

The genus Dunaliella is a unicellular marine green microalga (Prieto et al., 2011) that strives in a multitude of marine habitats such as oceans, brine lakes, salt marshes, salt lagoons and saltwater ditches near the sea. This halo-tolerant and cell wall-lacking microalga adapt to very high salinities. The tolerance is due to the capability of the microalgae in maintaining its energy-yielding processes at high rates (Alyabyev et al., 2011). The immense accumulation of carotenoids by some strains under favourable growth conditions has also guided to fascinating biotechnological applications (Oren, 2005). Dunaliella is renown in having the ability to accumulate high levels of carotenoids. Therefore, it has been selected as an important genus for the commercial production of food colouring agents, supplement for food and animal feed and an additive to cosmetics (Edge et al., 1997). 
Dunaliella synthesises photosynthetic pigments such as chlorophylls, carotenoids, and phycobilins (Takaichi, 2011; Borowitzka, 2013) in their cells. Carotenoids such as xanthophylls - violaxanthin, antheraxanthin, zeaxanthin, neoxanthin, lutein, loroxanthin, astaxanthin, canthaxanthin, fucoxanthin and $\beta$ carotene are commonly found in microalgae (Takaichi and Mochimaru, 2007). The carotenoid accumulation is not only influenced by the salinity but also governed through the culture growth phase and is usually extracted during the exponential phase (Fazeli et al., 2005). The pigment is produced in response to adverse environmental conditions for it has the ability to mob up excessive free radicals formed during these stressful conditions in the cell, thus restoring its physiological balance (Moller et al., 2000; Pisal and Lele, 2005). Carotenoids have a more significant commercial interest (Fazeli et al., 2006) over chlorophylls as they are applied in various fields of production.

Salinity would be the cheapest method of manipulating, controlling, and maintaining the growth environment for higher carotenoid production over temperature and irradiance control, since both involve a higher usage of electricity to maintain the controlled conditions of the culture (Coesel et al., 2008). Therefore, the objectives of this study were to determine the optimum salinity of the local strain of $D$. salina (Dunal) Teodoresco, 1905 for optimum growth and to evaluate the optimum salinity for the highest production and accumulation of total carotenoids.

\section{Materials and Methods}

\section{Sample collection, culture and maintenance}

Dunaliella salina was isolated from the South China Sea and the stock was preserved at Live Feed Laboratory, Institute of Tropical Aquaculture, Universiti Malaysia Terengganu. Sterilised and filtered seawater $(0.5 \mathrm{M} ; 8.0 \mathrm{pH})$ was used along with Conway medium (Tompkins et al., 1995) to culture D. salina. To allow sufficient time for $\mathrm{CO}_{2}$ equilibration the sterilised medium was kept for 2 days before microalga inoculation. Every 2 weeks sub-culturing was done to maintain pure and healthy stock. The pure and healthy stock culture was used for the experiment.

\section{Media preparation}

Conway medium was prepared according to Tompkins et al. (1995). Conway medium consists of macronutrients, trace metal solutions and vitamins (Table 1). One millilitre of macronutrient, $0.5 \mathrm{~mL}$ of trace metal, and $0.1 \mathrm{~mL}$ of vitamins were added to $1000 \mathrm{~mL}$ of filtered and sterilised seawater. Salinity was adjusted at $0.5 \mathrm{M}$ before inoculation of pure microalgae culture.
Table 1. Chemical composition of Conway medium.

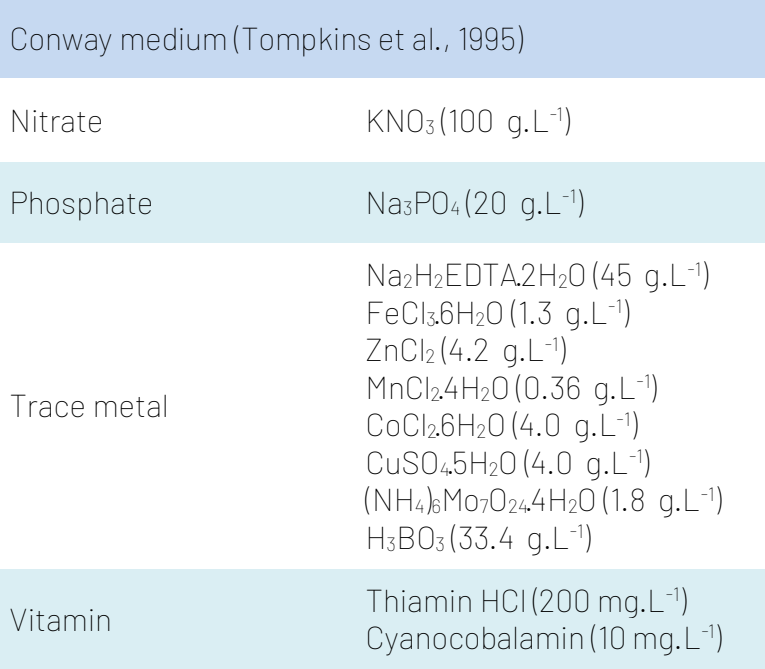

\section{Experimental design}

Dunaliella salina was grown in sterile $1 \mathrm{~L}$ Erlenmeyer flasks containing Conway medium (Tompkins et al., 1995) with increasing sodium chloride (Sigma, USA) concentrations of $0.3 \mathrm{M}, 0.5 \mathrm{M}, 0.7 \mathrm{M}$ and $0.9 \mathrm{M}$. The $\mathrm{pH}$ of the medium was adjusted to 8 by the addition of $1 \mathrm{M}$ $\mathrm{NaOH}$ (Sigma, St. Louis, MO, USA). The medium was inoculated with $1.5 \times 10^{6}$ cells from the stock culture of the isolates. Cells were grown at $24 \pm 1{ }^{\circ} \mathrm{C}$ under continuous illumination of $300 \mu \mathrm{mol} \mathrm{m}{ }^{-2} \mathrm{~s}^{-1}$ (adapted and modified from Fazeli et al., 2006). Light intensities were measured routinely with a quantum light meter (Fieldscout, Spectrum ${ }^{\oplus}$ Technologies, Inc., USA). Three replicates were made for each concentration. The cultures were aerated moderately and sterile cotton plugged at the mouth of the flasks to reduce contamination. Samples of the cultures were examined under the microscope for contamination throughout the experiment. The growth parameters and carotenoid accumulation between these four salinities were observed for 12 days (Prieto et al., 2011).

\section{Cell density and specific growth rate (SGR)}

Cell density was determined by cell count daily for each set of salinity and its replicates. Samples were taken from each set of salinity and its replicates every 2 days for carotenoid extraction to determine their pigment concentrations via optical density. Cell density was used to measure the growth of $D$. salina. An aliquot of well-mixed culture suspension was placed on a Neubauer haemocytometer (Assistant, Germany) to count the cell numbers daily for growth monitoring. Cells were tallied in five tiny quadrangles of the central block. Total cell numbers in culture were then estimated by volume and dilution. 
The specific growth rate (SGR) of D. salina from different treatments were calculated by the following equation (Clesceri et al., 1989):

$\operatorname{SGR}\left(\mu\right.$. day $\left.^{-1}\right)=\ln \times 2-\ln \times 1 /$ t2-t1

where $\mathrm{X} 1$ is the cell concentration at the beginning of the selected time interval, $\mathrm{X} 2$ is cell concentration at the end of the selected time interval, t2-t1 is the selected time (11 days) for the determination of cell density of $D$. salina.

\section{Carotenoid determination}

A $1 \mathrm{~mL}$ aliquot of the algal suspension from each culture was taken at an interval of 2 days and centrifuged at $1000 \times \mathrm{g}$ for $5 \mathrm{~min}$. The pellet obtained was extracted with $3 \mathrm{~mL}$ of ethanol:hexane 2:1 (v/v). Two millilitres of water and $4 \mathrm{~mL}$ hexane (Sigma, USA) was added to the mixture. It was shaken vigorously and centrifuged again at $1000 \times g$ for 5 min. The hexane layer separated and its absorbance (A) was determined spectrophotometrically at a wavelength of $450 \mathrm{~nm}$. The amount of extracted carotene from the samples in micrograms was determined by multiplying the absorbance $A_{450}$ with 25.2 (Shaish et al., 1992).

\section{Statistical analysis}

The quantitative analysis for cell growth and carotenoid concentration was performed in triplicates by the one-way analysis of variance (ANOVA). Fisher's individual error rate test was applied to resolve the significance between means. The data were expressed as means \pm standard error (SE) at a level of $P<0.05$ which was considered as significant (Fazeli et al., 2005; Hu et al., 2008). Pearson's correlation was used to determine the correlation between cell densities and carotenoid production for each set of salinity.

\section{Results}

\section{Cell density}

The highest growth of $D$. salina was observed with $2.35 \times 10^{6} \pm 0.12$ cells. $\mathrm{mL}^{-1}$ at $0.3 \mathrm{M}$ salinity and with $2.30 \times 10^{6} \pm 0.20$ cells. $\mathrm{mL}^{-1}$ at $0.5 \mathrm{M}$ salinity both achieved on day 11. Meanwhile, the highest growth for salinities $0.7 \mathrm{M}$ and $0.9 \mathrm{M}$ were observed on day 7 (6.95 $\times$ $10^{6} \pm 0.00$ cells. $\left.\mathrm{mL}^{-1}\right)$ and day $6\left(1.40 \times 10^{6} \pm 0.05\right.$ cells. $\mathrm{mL}^{-1}$ ), respectively (Fig. 1). In addition, at the end of the experiment, SGR was found to be higher $(P<$ $0.05)$ with $D$. salina cultured at $0.7 \mathrm{M}$ salinity $\left(0.53\right.$ day $\left.^{-1}\right)$ followed by $0.9 \mathrm{M}\left(0.50\right.$ day $\left.^{-1}\right), 0.3 \mathrm{M}\left(0.47\right.$ day $\left.^{-1}\right)$, and, $0.5 \mathrm{M}$ (0.41 day $\left.^{-1}\right)$ salinity (Table 2). The salt concentration of $0.7 \mathrm{M}$ favours the highest growth of the microalgae with a significant difference in growth $(P<0.05)$ compared to the rest of the treatments.

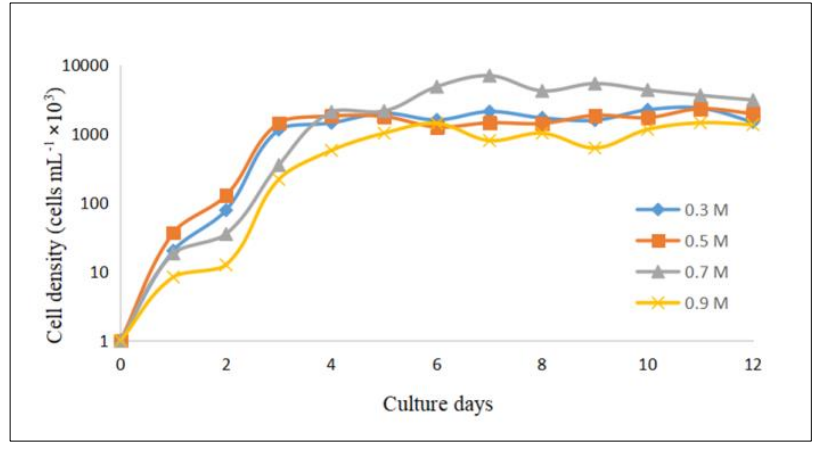

Fig. 1. Cell density $\left(\times 10^{3}\right)$ cells. $\mathrm{mL}^{-1}$ of Dunaliella salina cultured at different salinities. Values are mean \pm standard error.

Table 2. Specific growth rate of Dunaliella salina cultured at different salinities.

\begin{tabular}{ll}
\hline Treatments & $\begin{array}{l}\text { Specific growth rate } \\
\text { (SGR } \mu . \text { day }^{-1} \text { ) }\end{array}$ \\
\hline $0.3 \mathrm{M}$ & $0.476 \pm 0.01$ \\
$0.5 \mathrm{M}$ & $0.413 \pm 0.03$ \\
$0.7 \mathrm{M}$ & $0.530 \pm 0.02$ \\
$0.9 \mathrm{M}$ & $0.504 \pm 0.05$ \\
\hline
\end{tabular}

Values are mean \pm standard error.

\section{Carotenoid accumulation}

Total carotenoid content ranged from $0.139 \mathrm{mg} \cdot \mathrm{L}^{-1}$ at $0.3 \mathrm{M}$ salinity to $5.015 \mathrm{mg} \cdot \mathrm{L}^{-1}$ at $0.7 \mathrm{M}$ salinity (Fig. 2). The highest carotenoid accumulations were detected at $0.88 \pm 0.04$ (Day 10), $0.84 \pm 0.03$ (Day 10), $5.01 \pm 0.00$ (Day 6 ) and $1.72 \pm 0.13 \mathrm{mg} \cdot \mathrm{L}^{-1}$ (Day 2 ) for salinities 0.3 , $0.5,0.7$ and $0.9 M$, respectively (Fig. 2). The salt concentration of $0.7 \mathrm{M}$ favours the highest $(P<0.05)$ carotenoid production of the microalga compared to the rest of the treatments (Fig. 2). A strong positive correlation was discovered between cell density and carotenoid production (Table 3).

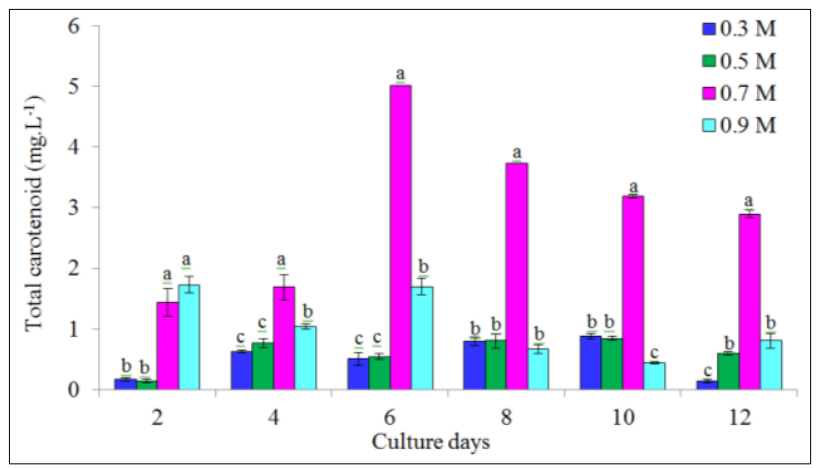

Fig. 2. Carotenoid production (mg. $\mathrm{L}^{-1}$ ) of Dunaliella salina cultured at different salinities. Values are mean \pm standard error. 
Table 3. Pearson's correlation value for Dunaliella salina cultured at different salinities.

\begin{tabular}{|c|c|c|c|c|}
\hline & \multicolumn{4}{|c|}{ Different treatments } \\
\hline & $0.3 \mathrm{M}$ & $0.5 \mathrm{M}$ & $0.7 \mathrm{M}$ & $0.9 M$ \\
\hline \multirow{3}{*}{ Correlation } & 0.736 & 0.738 & 0.894 & 0.783 \\
\hline & & \pm & & \\
\hline & $0.01^{b}$ & $0.01^{b}$ & $0.02^{a}$ & $0.01^{b}$ \\
\hline
\end{tabular}

Values are mean \pm standard error.

\section{Discussion}

Dunaliella salina is a type of unicellular and halophilic green biflagellate microalga without a rigid cell wall structure (Ben-Amotz and Avron, 1992). Dunaliella salina is renowned in having the ability to accumulate high levels (4.2-5.29 mg. $\mathrm{g}^{-1}$ ) of carotenoids (Chagas et al., 2015). Therefore, it has been selected as an important species for food colouring agents, a provitamin a supplement for food and animal feed, an additive to food and cosmetics, a health food product (Edge et al., 1997).

Based on the location of the isolated species and culture condition growth may vary for $D$. salina as shown in Table 4.

Table 4. Cell density (cells. $\mathrm{mL}^{-1}$ ) of Dunaliella salina cultured at different salinities.

\begin{tabular}{lll}
\hline Salinity (M) & $\begin{array}{l}\text { Cell } \\
\text { density } \\
\left(\text { cells. } \mathrm{mL}^{-1}\right)\end{array}$ & References \\
\hline 0.4 & $3.48 \times 10^{5}$ & Hamed et al. (2017) \\
0.6 & $1.50 \times 10^{5}$ & Hamed et al. (2017) \\
0.7 & $6.95 \times 10^{6}$ & Present study \\
\hline
\end{tabular}

The optimum salinity for the growth of $D$. salina is $2 M$ (Hadi et al., 2008). However, higher salinities have been reported to retard growth rates but increase the carotenoid levels in them (Fazeli et al., 2005). In the present study, D. salina was capable of growing at all the salinities tested. Generally, D. salina prefers a moderately high salinity $(0.7 \mathrm{M})$ rather than a low salinity $(0.3 \mathrm{M})$ or extremely high salinity $(0.9 \mathrm{M})$. Therefore, Malaysian D. salina demonstrated a higher growth rate at optimum salinity (0.7M). When comparing the results with other findings, there are discrepancies as more factors are involved in affecting the growth rate of the microalgae, including temperature, light, aeration, species, strains, temperature, irradiance, medium used, and culture period. Temperature and light are the two most important parameters that influence microalgal growth and are dependent on each other. The optimal
$\mathrm{pH}$ for growth of most of the algal species should be between 7.0 and 9.0, although some species that dwell in both acidic and basic environments are also existent (Blinova' et al., 2015). In addition, the amount of major and minor nutrients in the medium also plays a crucial role in microalgae growth. The importance of the effect of change in $\mathrm{pH}$, salinity, and carbon dioxide on microalgal growth solely depends on the species (freshwater or marine) under microalgae study.

To optimise the microalgae growth, it is essential to control the temperature while culturing microalgae as temperature plays a crucial role in the growth of microalgae (Raven and Geider, 1988). Temperature affects the gross photosynthetic activity of microalgae by undergoing cellular division, which, in turn, affects the biomass productivity of microalgae. Dunaliella is able to withstand a temperature range between $0{ }^{\circ} \mathrm{C}$ and $45^{\circ} \mathrm{C}$. The ideal growth of Dunaliella $\mathrm{sp}$. was determined at $32{ }^{\circ} \mathrm{C}$ with a wide growth temperature span ranging between $25^{\circ} \mathrm{C}$ and $35^{\circ} \mathrm{C}$ (Hosseini Tafreshi and Shariati, 2009). In the present study, the temperature controlled at $26^{\circ} \mathrm{C}$.

Light is vital for microalgae growth and varies with culture density. Light intensity and photoperiod cycles are one of the key factors that may limit or maximise the growth of microalgae cultivation (Parmar et al., 2011). Concentrated microalgae cultured need higher intensity of light to penetrate through the culture (Wahidin et al., 2013). However, if the light intensity is too high, it may inhibit the growth of microalgae or known as photo-inhibition and decrease the photosynthetic rate (Mulders et al., 2014). Most microalgae can tolerate light saturation up to 1700 to $2000 \mu \mathrm{mol} \mathrm{m}{ }^{-2} \mathrm{~s}^{-1}$ (Griffiths, 2013). When exposed to high light, the Dunaliella cells are reported to use the carotenoid synthesis pathway as a protective mechanism against photodamage (Mulders et al., 2014). Different Dunaliella strains may vary significantly in their response to light stress and show different sensitivities to the light intensities. However, it is not clear as to whether high or low irradiance is more effective in stimulating the synthesis of 9 -cis $\beta$-carotene (Orset and Young, 2000).

Majority of microalgal species growth is known to prefer at neutral $\mathrm{pH}$ and all strains of microalgae seem to have a limited optimal range of $\mathrm{pH}$ (Lutzu, 2012). The effect of photoperiod on the growth of $D$. salina CCAP 19/30 revealed that longer photoperiods led to increased growth of microalgae with higher cell densities (Xu et al., 2016). Growth of microalgae is directly proportional to the uptake rate of the most limiting nutrients. Nitrogen and phosphorous are considered to be the primary nutrient for microalgae growth. In this experiment, the commercial media was used where nitrogen and phosphorous are major nutrients. Nitrogen is considered to be a building 
block for proteins and nucleic acids, whereas phosphorus forms parts of phospholipids.

In addition to the higher growth rate, Dunaliella preferred 0.7 salinity for the accumulation of carotenoid during the exponential phase (from Day 3 to Day 7). In response to several stress factors or growth-limiting conditions such as salinity, temperature, light, and nutrient deficiencies (BenAmotz and Shaish, 1992; Fazeli et al., 2005; Mojaat et al., 2008), D. salina synthesises and accumulates $\beta$ carotene in lipid globules in the stroma of chloroplasts. The extent of carotenoids accumulation in oil globules within the inter-thylakoid spaces of their chloroplast is directly proportional to the integral amount of light to which D. salina cells are exposed during a division cycle (Ben-Amotz and Avron, 1983). The pigment has the ability to mob up excessive free radicals formed during these stressful conditions in the cell, thus restoring its physiological balance (Pisal and Lele, 2005). Accumulation is enhanced under several harmful conditions such as high irradiance, stress temperatures, high salt concentration and/or nutrient deficiency (Ben-Amotz and Shaish, 1992). Under these conditions, up to $10 \%$ of the algae dry weight is $\beta$-carotene. Dunaliella $\beta$-carotene occurs as a number of isomers, two of which, 9-cis and all-trans, make up approximately $80 \%$ of the total isomers (Prieto et al., 2011).

A study done by Fazeli et al. (2005) showed that low salinities of $0.1 \mathrm{M}$ and $0.5 \mathrm{M} \mathrm{NaCl}$ favoured both total carotenoids and chlorophyll-a production by $D$. tertiolecta when compared on a volume basis. However, productivity on a cellular basis (per gram of total carotenoids and chlorophyll-a per cell) was significantly higher at extreme salt concentration (3M $\mathrm{NaCl}$ ). Although high salinity favoured total carotenoid production by $\mathrm{D}$. tertiolecta on a cellular basis, it negatively affected on a per-volume basis because cell growth was repressed at elevated salt concentrations. In another study by Marin et al. (1998), they reported that the adjustment of light in combination with salinity is the best methods to achieve optimal carotene production in commercial cultures of $D$. salina.

In the present study, the highest carotenoid concentration of $5.015 \mathrm{mg} . \mathrm{L}^{-1}$ (Day 6) was found at 0.7M. In a separate study, Hadi et al. (2008) have reported that $1.66 \mathrm{mg} . \mathrm{L}^{-1}$ of total carotenoid was extracted from $D$. viridis at $1.0 \mathrm{M}$ salinity. However, the findings of the present study showed that the Malaysian D. salina is capable of accumulating 1.730 mg. $\mathrm{L}^{-1}$ (Day 2) carotenoid at only $0.7 \mathrm{M}$ salinity, using different media and irradiance compared to other studies. The local D. salina may, therefore, have the potential to accumulate higher amounts of carotenoids if cultured at higher salinities.

\section{Conclusion}

The microalgae had the maximum growth rate and highest total carotenoid accumulation at $0.7 \mathrm{M}$ salinity. Therefore, the local strain Dunaliella salina can be regarded to have an optimum salinity for growth and total carotenoid accumulation at $0.7 \mathrm{M}$ salinity as compared to other salinities $(0.3,0.5$ and $0.9 \mathrm{M})$. The results of this study can be applied in the production of carotenoid from the local strain of $D$. salina for application in the food industry, pharmaceutical, cosmeceutical and also aquaculture. Further studies are required to do mass cultivation of D. salina at the optimum salinity (0.7M) for open outdoor cultures (such as open tanks) and closed cultures (such as tubular reactors) to utilise the biomass in different industries.

\section{Acknowledgements}

This study was supported by the Ministry of Higher Education, Malaysia, through Fundamental Research Grant Scheme (FRGS) project No. FRGS/1/2015/WAB01/UMT/03/6.

\section{References}

Alyabyev, A., Andreyeva, I., Rachimova, G. 2011. Influence of pH shift and salting on the energetics of microalgae Chlorella vulgaris and Dunaliella maritima. Journal of Thermal Analysis and Calorimetry 104:201-207. https://doi.org/10.1007/s10973-010-1247-1

Ben-Amotz, A. 1996. Effect of low temperature on the stereoisomer composition of $\beta$-carotene in the halotolerant alga Dunaliella bardawil (Chlorophyta). Journal of Phycology 32:272-275. https://doi.org/10.1111/j.0022-3646.1996.00272.x

Ben-Amotz, A., Avron, M. 1983. On the factors which determine massive $\beta$-carotene accumulation in the halotolerant alga Dunaliella bardawil. Plant Physiology 72:593-597. https://doi.org/10.1104/pp.72.3.593

Ben-Amotz, A., Avron, M. 1992. Dunaliella: Physiology, biochemistry, and biotechnology. CRC Press, Boca Raton, Florida. 256 pp.

Ben-Amotz, A., Katz, A., Avron, M. 1982. Accumulation of $\beta$-carotene in halotolerant algae: purification and characterization of $\beta$-carotenerich globules from Dunaliella bardawil (Chlorophyceae). Journal of Phycology 18:529-537. https://doi.org/10.1111/j.15298817.1982.tb03219.x

Ben-Amotz, A., Shaish, A. 1992. B-carotene biosynthesis. In: Dunaliella: Physiology, biochemistry, and biotechnology. Avron, M., BenAmotz, A. (Eds.), CRC Press, Boca Raton, Florida, pp. 205-216.

Blinova', L., Bartošova', A., Gerulova', K. 2015. Cultivation of microalgae (Chlorella vulgaris) for biodiesel production. Research Papers Faculty of Materials Science and Technology, Slovak University of Technology 23:87-95. https://doi.org/10.1515/rput-2015-0010

Borowitzka, M.A. 2013. High-value products from microalgae - their development and commercialization. Journal of Applied Phycology 25:743-756. https://doi.org/10.1007/s10811-013-9983-9

Borowitzka, M.A., Borowitzka, L.J., Kessly, D. 1990. Effects of salinity increase on carotenoid accumulation in the green algae Dunaliella salina. Journal of Applied Phycology 2:111-119. https://doi.org /10.1007/BF00023372

Chagas, A.L., Rios, A.O., Jarenkow, A., Marcilio, N.R., Ayub, M.A.Z., Rech, R. 2015. Production of carotenoids and lipids by Dunaliella 
tertiolecta using $\mathrm{CO}_{2}$ from beer fermentation. Process Biochemistry 50:981-988. https://dx.doi.org/10.1016/j.procbio.2015.03.012

Clesceri, L.S., Greenberg, A.E., Trussel, R.R. 1989. Standards methods for the examination of water and wastewater. $17^{\text {th }}$ Edition. American Public Health Association, Washington, DC. 1268 pp.

Coesel, S.N., Baumgartner, A.C., Teles, L.M., Ramos, A.A., Henriques, N.M., Cancela, L., Serafim Varela, J.C. 2008. Nutrient limitation is the main regulatory factor for carotenoid accumulation and for Psy and Pds steady state transcript levels in Dunaliella salina (Chlorophyta) exposed to high light and salt stress. Marine Biotechnology 10:602611. https://doi.org/10.1007/s10126-008-9100-2

Davidi L., Levin, Y., Ben-Dor, S., Pick, U. 2015. Proteome analysis of cytoplasmatic and plastidic $\beta$-carotene lipid droplets in Dunaliella bardawil. Plant Physiology 167:60-79. https://doi.org/10.1104 /pp.114.248450

Del Campo, J.A., García-Gonzáles, M., Guerrero, M.G. 2007. Outdoor cultivation of microalgae for carotenoid production: current state and perspectives. Applied Microbiology and Biotechnology 74:11631174. https://doi:10.1007/s00253-007-0844-9

Edge, R., McGarvey, D.J., Truscott, T.G. 1997. The carotenoids as antioxidants: a review. Journal of Photochemistry and Photobiology B: Biology 41:189-200. https://doi.org/10.1016/S1011-1344(97)00092-4

Fazeli, M.R., Tofighi, H., Samadi, N., Jamalifar, H. 2005. Effects of salinity on $\beta$-carotene production by Dunaliella tertiolecta DCCBC26 isolated from the Urmia salt lake, north of Iran. Bioresource Technology 97:2453-2456. https://doi.org/10.1016 /j.biortech.2005.10.037

Fazeli, M.R., Tofighi, H., Samadi, N., Jamalifar, H., Fazeli, A. 2006. Carotenoids accumulation by Dunaliella tertiolecta (Lake Urmia isolate) and Dunaliella salina (CCAP 19/18 and WT) under stress conditions. DARU Journal of Pharmaceutical Sciences 14:146-150.

Griffiths, M. 2013. Microalgal cultivation reactor systems. In: Biotechnological applications of microalgae: biodiesel and valueadded products, Bux, F. (Ed.), CRC Press, Taylor \& Francis Group, Boca Raton, Florida, pp. 51-75.

Hadi, M.R., Shariati, M., Afsharzadeh, S. 2008. Microalgal Biotechnology: carotenoid and glycerol production by the green algae Dunaliella isolated from the Gave-Khooni Salt Marsh, Iran. Biotechnology and Bioprocess Engineering 13:540-544. https://doi.org/10.1007/s12257$\underline{007-0185-7}$

Hamed, I., Burcu, A.k., Isik, O., Uslu, L. 2017. The effects of salinity and temperature on the growth of Dunaliella sp. isolated from the Salt Lake (Tuz Gölü), Turkey. Turkish Journal of Fisheries and Aquatic Sciences 17:1367-1372. https://doi.org/10.4194/1303-2712-v17_6_29

Hosseini Tafreshi, A., Shariati, M. 2009. Dunaliella biotechnology: Methods and applications. Journal of Applied Microbiology 107:14-35. https://doi.org/10.1111/j.1365-2672.2009.04153.x

Hu C.C., Lin, J.T., Lu, F.J., Chou, F.P., Yang, D.J. 2008. Determination of carotenoids in Dunaliella salina cultivated in Taiwan and antioxidant capacity of the algal carotenoid extract. Food Chemistry 109:439446. https://doi.org/10.1016/j.foodchem.2007.12.043

Kleinegris, D., Janssen, M., Brandenburg, W.A., Wijffels, R.H. 2009. The selectivity of milking of Dunaliella salina. Marine Biotechnology 12:1423. https://doi: 10.1007/s10126-009-9195-0

Lamers, P.P., Janseen, M., De-Vos, R.C.H., Bino, R.J., Wijffels, R.H. 2012. Carotenoid and fatty acid metabolism in nitrogen-starved Dunaliella salina, a unicellular green microalga. Journal of Biotechnology 162:21-27. https://doi:10.1016/j.jbiotec.2012.04.018

Lutzu, G.A. 2012. Analysis of the growth of microalgae in batch and semi-batch photobioreactors. PhD Thesis. Universita'degli Studi di Cagliari. 179 pp.
Marin, N., Morales, F., Lodeiros, C., Tamigneaux, E. 1998. Effect of nitrate concentration on growth and pigment synthesis of Dunaliella salina cultivated under low illumination and preadapted to different salinities. Journal of Applied Phycology 10:405-411. https://doi.org /10.1023/A:1008017928651

Mojaat, M., Pruvost, J., Foucault, A., Legrand, J. 2008. Effect of organic carbon sources and $\mathrm{Fe}^{2}+$ ions on growth and $\beta$-carotene accumulation by Dunaliella salina. Biochemical Engineering Journal 39:177-184. https://doi.org/10.1016/j.bej.2007.09.009

Moller, A.P., Biard, C., Blount, J.D., Houston, D.C., Nini, P. 2000. Carotenoid-dependent signals: Indicators of foraging efficiency, immunocompetence or detoxification ability? Avian and Poultry Biology Reviews 11:137-159. https://doi.org/10.1186/1746-1448-1-1

Mulders, K.J.M., Lamers, P.P., Martens, D.E., Wijffels, R.H. 2014. Phototrophic pigment production with microalgae: biological constraints and opportunities. Journal of Phycology 50:229-242. https://doi.org/10.1111/jpy. 12173

Oren, A. 2005. A hundred years of Dunaliella research: 1905-2005. Saline Systems 1:1-14. https://doi.org/10.1186/1746-1448-1-2

Orset, S., Young, A. 2000. Exposure to low irradiances favors the synthesis of 9 -cis $\beta, \beta$-carotene in Dunaliella salina (Teod.). Plant Physiology 122:609-617. https://doi.org/10.1104/pp.122.2.609

Parmar, A., Singh, N.K., Pandey, A., Gnansounou, E., Madamwar, D. 2011. Cyanobacteria and microalgae: a positive prospect for biofuels. Bioresource Technology 102:10163-10172. https://doi.org/10.1016 lj.biortech.2011.08.030

Pisal, D.S., Lele, S.S. 2005. Carotenoid production from microalgae, Dunaliella salina. Indian Journal of Biotechnology 4:476-483.

Prieto, A., Cañavate, J.P., García-González, M. 2011. Assessment of carotenoid production by Dunaliella salina in different culture systems and operation regimes. Journal of Biotechnology 151:180185. https://doi.org/10.1016/j.jbiotec.2010.11.011

Raven, J.A., Geider, R.J. 1988. Temperature and algal growth. New Phytologist 110:441-461 https://doi.org/10.1111/j.14698137.1988.tb00282.x

Shaish, A., Avron, M., Pick, U., Ben-Amotz, A. 1993. Are active oxygen species involved in induction of beta-carotene in Dunaliella bardawil. Planta 190:363-368. https://doi.org/10.1007/BF00196965

Shaish, A., Ben-Amotz, A., Avron, M. 1992. Biosynthesis of $\beta$-carotene in Dunaliella. Method of Enzymology 213:439-444. https://doi.org /10.1016/0076-6879(92)13145-N

Takaichi, S. 2011. Carotenoids in algae: Distributions, biosyntheses and functions. Marine Drugs 9:1101-1118. https://doi.org/10.3390 Imd9061101

Takaichi, S., Mochimaru, M. 2007. Carotenoids and carotenogenesis in cyanobacteria: Unique ketocarotenoids and carotenoids glycosides. Cellular and Molecular Life Sciences 64:2607-2619. https://doi.org /10.1007/s00018-007-7190-z

Tompkins, J., Deville, M.M., Day, J.G., Turner, M.F. 1995. Catalogue of strains: Culture collection of algae and protozoa. Titus Wilson \& Son Limited, Ambleside. 204 pp.

Wahidin, S., Idris, A., Shaleh, S.R.M. 2013. The influence of light intensity and photoperiod on the growth and lipid content of microalgae Nannochloropsis sp. Bioresource Technology 129:7-11. https://doi.org/10.1016/j.biortech.2012.11.032

Xu, Y., Ibrahim, I.M., Harvey, P.J. 2016. The influence of photoperiod and light intensity on the growth and photosynthesis of Dunaliella salina (chlorophyta) CCAP 19/30. Plant Physiology and Biochemistry 106:305-315. https://doi.org/10.1016/j.plaphy.2016.05.021 